\title{
THE ROLE OF INDEPENDENT DIRECTORS IN CORPORATE GOVERNANCE IN IT COMPANIES IN SERBIA
}

\author{
Danko Jevtović1 ${ }^{1 *}$ \\ Nikola Stefanović ${ }^{2}$ \\ ${ }^{1} \mathrm{PhD}$ candidate, \\ Singidunum University, \\ Belgrade, Serbia \\ ${ }^{2}$ Singidunum University, \\ Belgrade, Serbia
}

\begin{abstract}
:
The Serbian Companies Law of 2011 established a modern regulatory framework for corporate governance in Serbia and introduced the position of an independent director. The role of an independent corporate director is in resolving the agency problem between owners and management and in improving a group decision-making process in the governance of companies. This paper analyses acceptance and the role of independent corporate directors in Serbia and their influence on business decision-making processes. The research was conducted on a relevant sample of IT companies in Serbia, and it aims to analyse the role of independent directors in IT companies in Serbia and to assess how directors value the benefits of independent directors in the decision-making process.
\end{abstract}

Keywords:

corporate governance, independent directors, business decision making.

\section{INTRODUCTION}

Corporate governance is a well-developed concept in a market economy. The institution of independent directors is an essential part of the corporate governance framework designed to improve trust in corporations. In Serbia, the economy is still in transition, and it is not significantly corporatized (Begović et al. 2008). As no recent studies focus on the role of independent directors in the country, it is important to analyse the state of corporate governance and the establishment of the role of independent directors in IT companies. Accordingly, this paper aims to investigate the practice of Serbian companies in the IT sector and the attitude of directors (board members) of these companies.

The paper also aims to give recommendations on how to improve corporate governance at the board level and take advantage of the role of independent directors to reduce the risk of the groupthink. The authors believe that better corporate governance would result in more transparent and trustworthy Serbian IT companies and, consequentially, more investments in and growth of the economy.

\section{LITERATURE OVERVIEW}

International Finance Corporation (IFC, Corporate Governance Manual, 2007) defines corporate governance as "the structures and processes by which companies are directed and controlled". The Organisation for Economic Cooperation and Development (OECD) adopts corporate governance definition from the European Central Bank as "procedures and processes according to which an organisation is directed and controlled". 
In recent years, the number of scientific papers on corporate governance has increased substantially. Adams et al. (2010) estimate that "more than 200 working papers on boards have been written since 2003, when Hermalin and Weisbach published their original board literature survey". During that period, many other authors, such as Fields and Keys (2003), Carter et al. (2003), Farrell and Hersch (2005) contributed to this field.

Corporate governance is of utmost importance in generating investors' trust in companies. The McKinsey research finds, as reported by Watson et al. (2002), that, when making an investment decision, investors pay premiums for companies with good corporate governance. Researches also note that many as $63 \%$ of investors might avoid companies with poor governance, while as much as $33 \%$ of investors might completely avoid countries characterized as having poor governance.

Jansen and Meckling (1976) define the agency relationship as: "a contract under which one or more persons (the principal(s)) engage another person (the agent) to perform some service on their behalf which involves delegating some decision making authority to the agent". The European Corporate Governance Institute paper on Agency Problems, Legal Strategies and Enforcement (Armour et al., 2009) defines a potential conflict of interest between management and the company in making sure that professional management acts in the best interest of the owners (and not in their own self-interest). The institution of an independent director was designed to contribute to solving of the first agency problem (Jansen \& Meckling, 1976), and a historical overview was provided by Baum (2017). The significant improvements were based on the seminal recommendations of the Cadbury Report of the Committee on the Financial Aspects of Corporate Governance (Cadbury, 1993). Large corporate scandals (Hill, 2004) in the 2000s (Enron Corp. etc.) prompted a significant review and further development of the corporate governance and institution of independent directors in particular, as recommended in the UK in the Higgs Report (2003).

The literature (Pechersky 2016) shows that independence and diversity have a positive effect on the decisionmaking process and board performance. The groupthink (Whyte, 1952) can be reduced by more independence, as Da and Huang (2015) find that the final results (wisdom) of groups can be enhanced by encouraging independent voices. On the other hand, the question of measurable benefit of board independence on corporate performance is very much open, as Bhagat and Black (1999) find no evidence that board independence leads to improved performance, and as explained by Adams (2017).

In the Winter's Report (2002), the High-Level Group of Experts recommends that, in European Union, listed companies should make sure that their directors are independent and that their remunerations and any side dealing, which could lead to non-independence, are transparent.

\subsection{Independent directors in Serbia}

Significant regulatory changes followed the transition of the economy of Serbia. The Serbian Company Law of 2011 modernised the regulation of business entities in line with EU trends. Vasiljevic (2013) summarises that the Serbian Company Law is modern, ahead of its time, and that it incorporated many EU future guidelines.

The institution of an independent member of a management board was introduced by the Serbian Company Law of 2004, but only the new Company Law of 2011 clearly defined the role of an independent director (supervisory board member in a dual board), in line with the EU recommendations (Winter, 2002).

Independent director (Companies Law of Serbia, 2011, Art. 392) is a: "Person not affiliated to directors, and a person who, over the last two years: 1) Has not been an executive director, or employed in the company, or in some other company affiliated to the company in terms of [the] Law; 2) Has not owned more than $20 \%$ of the share capital, and has not been employed or otherwise hired by some other company which has generated more than $20 \%$ of its annual revenues from the company over that period; 3) Has not received payments from the company or its affiliated persons in terms of [the] Law; 4) Has not owned more than $20 \%$ of the share capital of a company affiliated with the company in terms of [the] Law; 5) Has not been engaged in the conduct of an audit of the company's financial statements." Furthermore, a statement of the application of a corporate governance code is obligatory for all public joint-stock (listed) companies in Serbia, and they are obliged to have at least one independent director.

There is a clear gap in the scientific literature and general business publication between recommendations on the institution of an independent director, on the one hand, and corporate governance practices in Serbian corporations on the other. Analysing that gap might help bring about recommendations that would point directions for governance improvements.

\section{HYPOTHESIS}

Taking into consideration the reasons for establishing the institution of independent directors, experiences in the EU, and the intent of the Serbian regulations, the aim of this paper is to assess whether the directors of Serbian IT companies value the role of independent directors in 
business decision-making processes as significant, and whether directors believe that independent directors reduce the groupthink risk.

\section{METHODOLOGY}

Belgrade Stock Exchange Prime Listing has only four companies, the Standard Listing has only three, and the unregulated market has only 432 listings ${ }^{1}$. Begović et al. (2008) found that: "The stock market in Serbia is relatively new and not very developed" (the quote by Petronijević, 2018). Therefore, the strength of corporate governance in a company is still not considered an essential mechanism for investors to evaluate the risks of investing.

This paper focuses on large IT companies in Serbia. It can reasonably be expected that technologically more modern companies could also be more modern organisationally. The companies were selected on the following criteria $^{2}$ (data from FY 2018, the most recent data available at the time of the research):

Table 1. Companies selection criteria

\begin{tabular}{ll}
\hline Revenue (FY 2018) & $>120,000,000$ dinars $(>€ 1 \mathrm{M})$ \\
\hline Employees & $>=50$ \\
\hline Business activity & IT-related \\
\hline Serbian companies & No representative offices \\
\hline
\end{tabular}

Table 2. Statistics for selected companies (FY 2018)

\begin{tabular}{ll}
\hline Number of companies & 83 \\
\hline Total employees & 10,549 \\
\hline Average employees & 127 \\
\hline Median employees & 85 \\
\hline Total revenue & $€ 1$ billion \\
\hline Average revenue & $€ 6$ million \\
\hline Median revenue & $€ 12$ million \\
\hline
\end{tabular}

Source: Authors' calculations

The companies in the selected group exhibit significant business difference. All the companies are in the IT sector based on the official classification of business activities. Still, they operate in different business lines (companies also vary in size, assets, and revenue).

The survey methodology ${ }^{3}$ focused on the questionnaire directed to individual directors in the selected companies.
For the research group, the authors selected all directors (authorised persons) from all selected IT companies.

Table 3. Directors (board members)

\begin{tabular}{ll}
\hline Selected companies & 83 \\
\hline Total directors & 269 \\
\hline Foreign citizens & $19 \%(52)$ \\
\hline Females & $18 \%(48)$ \\
\hline LinkedIn profiles & $73 \%(198)$ \\
\hline Questionnaire filled & $14 \%(37)$ \\
\hline Answers with an identifiable person & $11 \%(30)$ \\
\hline Response rate (total) & $14 \%$ \\
\hline Response rate (contacted) & $39 \%$ \\
\hline \multicolumn{2}{c}{ Source: Authors' calculations }
\end{tabular}

The surveyed persons were asked to self-evaluate the governance system in their company, the role of independent directors, and the influence of independent directors on the quality of business decisions.

\section{RESULTS AND DISCUSSION}

The results of the questionnaire showed the following:

Table 4. Survey results ${ }^{4}$

\begin{tabular}{ll}
\hline Directors answered & 37 \\
\hline Companies with answers & $30 \%(25 / 83)$ \\
\hline Foreign ownership & $54 \%(20)$ \\
\hline Minority shareholders exits & $62 \%(23)$ \\
\hline $\begin{array}{l}\text { Difference ownership vs } \\
\text { management }\end{array}$ & $78 \%(25)$ \\
\hline
\end{tabular}

Source: Authors' calculations

Table 5. Position in the company

\begin{tabular}{ll}
\hline CEO (general manager) & $46 \%(17)$ \\
\hline Executive director & $16 \%(6)$ \\
\hline Non-executive director & $2.7 \%(1)$ \\
\hline Independent director & $0 \%(0)$ \\
\hline Co-owner (informal board) & $5.4 \%(2)$ \\
\hline Authorised person & $24 \%(9)$ \\
\hline Other & $5.4 \%(2)$
\end{tabular}

Source: Authors' calculations

Based on the results, in the significant majority of the companies, the governance is important, as $78 \%$ $(n=25 / 32)$ of the respondents state that, in their companies, there is a difference between ownership and governance/management. However, governance structures are 
not well developed. Only $2.4 \%(n=2 / 83)$ companies are joint-stock companies (open/public or closed), and the rest are limited liability companies - not required to have boards. The respondents in $22 \%(n=7)$ said their companies have a formal board. In $88 \%(n=28)$ cases, the president of the board is CEO or the principal owner(s).

The non-executive directors are present in $41 \%$ of the companies $(n=13 / 32)$, but independent directors in just in one $(3 \% n=1 / 32)$.

\subsection{Opinions of the directors}

The observed opinions of the surveyed directors show that they value good governance practices more than can be implied from the observed patterns. The majority of responders $(56 \%, n=19 / 32)$ believe that the existence of independent directors is valuable for business decision-making.

In the companies that don't have independent directors, the majority of responders believe they don't need them. Only $21 \%(n=6 / 28)$ believe in some level of usefulness of independent directors ${ }^{5}$.

In the control question, most of the responders $(55 \%, \mathrm{n}=16)$ confirmed that independent directors have a duty of loyalty to the company. Still, significant number believes that an independent director owns loyalty to owner/shareholders $(31 \%, n=9)$, management $(7 \%, n=2)$ or to the one who appointed them $(7 \%, \mathrm{n}=2)$.

In the multiple-choice question: "What are the benefits of an independent director for the company?"

Table 6. Benefits of independent directors

\begin{tabular}{ll}
\hline They bring a new business outlook & $66 \%(19)$ \\
\hline They bring outside experiences & $52 \%(15)$ \\
\hline They improve the quality of business decisions & $48 \%(14)$ \\
\hline They improve deliberations in a board & $45 \%(13)$ \\
\hline They reduce the groupthink risks & $38 \%(11)$ \\
\hline They help in lobbying & $34 \%(10)$ \\
\hline
\end{tabular}

Source: Authors' calculations

Most of the respondents believe that independent directors reduce the risk of mistakes in the business decision due to the groupthink. The majority $(59 \% \mathrm{n}=17)$ believe it only partially ${ }^{6}$.

The survey results indicate possible ways to improve directors' understanding of their duties, board group dynamics, and, ultimately, the quality of the business decisions in the board. Only $12 \%(n=3 / 25)$ of the respondents had some form of onboarding training. The majority of respondents $(56 \% \mathrm{n}=14 / 25)$ state that their boards evaluate their performance, but from the comments, it was concluded that most of the evaluations are focused on the managerial KPIs, not on issues related to board governance. Only $12 \%(n=3 / 25)$ of the respondents declared that they had in-company nomination policy, in $28 \%(n=7)$ is the decision by the owner (shareholders assembly), but $60 \%(n=15)$ don't have any nomination policy.

One of the important global trends is the automatization of the decision-making process using business expert systems or AI technology. Even though surveyed directors are from IT companies, automatization in business decisions is not present. Only one $(4 \% \mathrm{n}=1 / 25)$ respondent is using $\mathrm{AI} /$ automatization, $20 \%(\mathrm{n}=5)$ are considering it, but the majority $76 \%(n=19)$ do not consider it at all.

\section{SUMMARY}

Corporate governance in emerging markets is not a well-researched subject. At the IFC Global Corporate Governance Forum, the researchers Ararat and Dallas (2011) find that less than $1 \%$ of corporate governance research papers focus on emerging markets. Most research that analyses global governance in emerging markets doesn't mention Serbia (Classens \& Yortoglu for IMF, 2012; Isaksson for OECD, 2019).

Researches in Serbian usually focus on governmentowned enterprises, banking sector or joint-stock corporations listed on Belex ${ }^{7}$, as some data is publicly available. The authors didn't find any study that examined the attitude of directors in the IT sector. Finally, the authors decided to base the conclusion and the recommendation on the perceived gap between generally accepted recommendations at the EU level and the practice observed in this research.

\subsection{Limits of the research and possible next steps}

The principal limit for this research was the structure of the economy in Serbia, and very few significantly larger joint-stock companies with well-developed governance in the selected IT sector (only $2.4 \%$ joint-stock companies) ${ }^{8}$.

The authors believe that similar research can be done on the directors of government-owned enterprises. Another interesting research, on the attitude of directors, could be done in the banking industry, as it is highly regulated with comparable financial reports, and with mandatory independent directors.

One of the exciting developments that can be expected in the future is the usage of $\mathrm{AI}$ and machine learning. One of the observed exciting ideas is to use machine learning algorithms to help select directors (Erel et al. 2018).

7 Belgrade Stock Exchange jsc, Belgrade, Serbia www.belex.rs/eng 8 Source: Authors' calculations. 


\subsection{Recommendations}

IT companies that want to improve trust and prepare for the future can do significant steps in the corporate governance area: 1) Formalize governance structure make a clear separation between ownership, governance, and management; 2) Include independent directors in the board; 3) Appoint a non-executive director as the board chair (or lead director); 4) Educate directors in the role of the board, their duties, and specifics of the group decisionmaking process; 5) Prepare onboarding process for newly appointed directors; 6) Analyse skills and diversity of directors and identify gaps that should be filled; 7) Formalize nomination policy (including independence) for selection and appointment of new directors; and 8) Have formal regular board self-evaluation and feedback for individual directors.

\section{CONCLUSION}

This paper analyses corporate governance practices in IT companies in Serbia. The research shows a significant disconnection between the development of formal governance structures in IT companies and the observed attitude of the surveyed directors.

The research also shows perceived lack of the need for a better governance structure in IT companies. Good governance is necessary to create a trust that is needed to attract capital by showing that investments and rights of minority shareholders and creditors are protected, and risks are managed.

The surveyed directors generally show more understanding of corporate governance that is needed in the Serbian IT business environment. Companies that want to attract investments will have to have proper governance structures and demonstrate successful management of the agency problems. That will require professional directors.

The authors believe that market and regulatory forces will drive the need for better governance, and that more research is needed to understand the specifics of the Serbian IT market.

\section{LITERATURE}

Adams, R. B. (2017). Boards, and the directors who sit on them. The handbook of the economics of corporate governance, 291-382

Adams, R. B., Hermalin, B. E., \& Weisbach, M. S. (2010). The role of boards of directors in corporate governance: A conceptual framework and survey. Journal of economic literature, 48(1), 58-107.

Ararat, M., \& Dallas, S. (2011). Corporate governance in emerging markets: why it matters to investors-and what they can do about it. Paper presented at the Private Sector Opinion, IFC Global Corporate Governance Forum. Retrieved September 23, 2020, from https://papers.ssrn. com/sol3/papers.cfm?abstract_id=1914267

Armour J., Hansmann H., \& Kraakman R. (2009). Agency Problems, Legal Strategies and Enforcement. European Corporate Governance Institute. 3. Retrieved September 23, 2020, from https://papers.ssrn.com/sol3/papers. cfm?abstract_id=1436555

Baum, H. (2017). The rise of the independent director: a historical and comparative perspective. Max Planck Private Law Research Paper No. 16/20.

Begović, B., Jovanović, J., Mijatović, B., Paunović, M., Vasović, M., \& Vuković, S. (2008) Corporate Governance: five years later (in Serbian), Korporativno upravljanje: pet godina kasnije, Centar za liberalno - demokratske studije, 22, 64,102 .

Bhagat, S., \& Black, B. (1999). The uncertain relationship between board composition and firm performance. The Business Lawyer, 54(3), 921-963.

Cadbury, A. (Sir). (1993). The Committee on the Financial Aspects of Corporate Governance, Financial Aspects of Corporate Governance. The London Stock Exchange. Retrieved September 23, 2020, from cadbury.cjbs.archios.info/report

Carter, D. A., Simkins, B. J., \& Simpson, W. G. (2003). Corporate governance, board diversity, and firm value. Financial Review, 38(1), 33-53.

Claessens S, \& Yurtoglu B. (2012). Corporate Governance in Emerging Markets: A Survey. International Monetary Fund. 15(1), 1-33.

Companies Law of Serbia (2011-19). Official Gazette of the Republic of Serbia 36/2011, 99/2011, 83/2014, 5/2015, $44 / 2018,95 / 2018$, and 91/2019.

Da, Z., \& Huang, X. (2015). Harnessing the Wisdom of Crowds. Management Science. 55(3), 1-21.

Erel, I., Stern, L. H., Tan, C., \& Weisbach, M. S. (2018). Selecting directors using machine learning (0898-2937). National Bureau of Economic Research. 1-53.

European Central Bank (2004). Annual Report. 219. Retrieved September 23, 2020, from https://www.ecb.europa.eu/ pub/pdf/annrep/ar2004en.pdf 
Farrell, K. A., \& Hersch, P. L. (2005). Additions to corporate boards: The effect of gender. Journal of Corporate Finance, 11(1-2), 85-106.

Fields, M. A., \& Keys, P. Y. (2003). The emergence of corporate governance from Wall St. to Main St.: Outside directors, board diversity, earnings management, and managerial incentives to bear risk. Financial Review, 38(1), 1-24.

Hermalin, B. E., Michael, S.E., \& Weisbach, M, S., (2003). Boards of Directors as an Endogenously Determined Institution: A Survey of the Economic Literature. Economic Policy Review, 9(1), 7-26.Higgs D. (2003). Review of the Role and Effectiveness of Non-executive Directors.

Hill, J. (2004). Corporate scandals across the globe: Regulating the role of the director. Reforming company and takeover law in Europe, 27-29.

IFC, World Bank (2007). Corporate Governance Manual. Retrieved September 23, 2020, from https://www.scribd. com/document/364389767/Corporate-GovernanceManual-New

Jensen M. \& Meckling W. (1976). Theory of the Firm: Managerial Behaviour, Agency Costs and Ownership Structure. Journal of Financial Economics,305-360.
OECD Corporate Governance Factbook. (2019). OECD Corporate Governance Committee. Retrieved September 23, 2020 , from www.oecd.org/corporate/corporate-governance-factbook.htm

Pechersky, A. (2016). Diversity in board of directors: Review of diversity as a factor to enhance board performance. Studia Commercialia Bratislavensia, 9(33), 88-101.

Petronijević D. (2018) Behavioral Economics: How Well Do Investors in Serbia Predict the Stock Prices? The European Journal of Applied Economics, 15(1), 112.

Vasiljević M. S. (2013). Korporativno upravljanje - Izabrane Teme (in Serbian), 24.

Watson, M., Coombes P., McKinsey \& Company (2002). Governance is increasingly at the heart of investment decisions. McKinsey Global Investor Opinion Survey.

Whyte, W. H., Jr. (1952). Groupthink. Fortune (March), 114-117, 142,146

Winter J., etal. (2002). Report if the High-Level Group of Company Law Experts on a Modern Regulatory Framework for Company Law in Europe (Winter Report), 75-76. 